\title{
EMPIRICAL ASSESSMENT OF THE IMPACT OF VDC AND LEAN ON ENVIRONMENT AND WASTE IN MASONRY OPERATIONS
}

\author{
Musab Maraqa ${ }^{1}$, Rafael Sacks ${ }^{2}$, and Sabrina Spatari ${ }^{3}$
}

\begin{abstract}
Lean principles aim to improve construction through focus on value and waste elimination, which benefits environmental performance by reducing life cycle greenhouse gas (GHG) emissions and improving other environmental metrics. Although prior research identified relationships between Lean, BIM and sustainability, most studies were qualitative assessments of the value of lean and VDC management. In this study we measured the impact of Lean and VDC on waste in operations, and on GHG emissions, of masonry partitions. Researchers observed workers and classified their activities as value-adding or non-value-adding. Data from three different projects that include combinations of Lean and VDC implementation were used to estimate the efficiency of operations in comparison to earlier construction projects from 2007 to 2014 that implemented the same methods. The results were eye-opening: implementing Lean principles and VDC raised the proportion of value-adding activities to $68.4 \%$, compared to only $35.8 \%$ in traditional management. Moreover, Lean and VDC methods contributed to reduce wasted global warming potential (GWP) from $169 \mathrm{~kg} \mathrm{CO} \mathrm{e}_{2} / \mathrm{m}^{3}$ of partition built to $112 \mathrm{~kg} \mathrm{CO} 2 \mathrm{e} / \mathrm{m}^{3}$, an environmental improvement of $34 \%$. Lean and VDC are dominant management approaches in reducing waste and improving sustainability.
\end{abstract}

\section{KEYWORDS}

Lean construction, masonry walls, Virtual Design and Construction (VDC), sustainability, waste

\section{INTRODUCTION}

As cities around the world grow, urban development and demand for infrastructure, housing and health, education and service facilities are expected to rise. However, activities associated with construction introduce environmental impacts, including greenhouse gases (GHG), which are the main contributor to global warming and climate change, primarily due to upstream emissions related to the production of building materials (Fu et al. 2015). Therefore, any effort to reduce the waste generated during

1 MSc Graduate Student, Faculty of Civil and Enviromental Engineering, Technion - Israel Institute of Technology, Haifa, Israel, +972 58670 2922, musab maraqa@hotmail.com, orcid.org/0000-00027756-2787.

2 Professor, Faculty of Civil and Enviromental Engineering, Technion - Israel Institute of Technology, Haifa, Israel, +972 4829 3190, cvsacks@technion.ac.il, orcid.org/0000-0001-9427-5053.

3 Associate Professor, Faculty of Civil and Enviromental Engineering, Technion - Israel Institute of Technology, Haifa, Israel, +972 54668 4373, ssabrina@ttechnion.ac.il, orcid.org/0000-0001-7243$\underline{9993 .}$ 
construction will reduce environmental impacts along construction material supply chains. Furthermore, the construction industry is one of the most material and energy consuming industries worldwide, contributing also to the emission of pollutants across the life cycle (Horvath 2004). For these reasons, sustainability decision metrics are greatly needed to guide better design and construction of buildings and infrastructure. Life cycle assessment (LCA) is a valuable tool that can guide the sustainable design of products, processes, and activities. In recent years, LCA has been used to evaluate a variety of decisions in building material production (Stadel et al. 2011) and recycling (McIntyre et al. 2009) and civil engineering infrastructure, including construction (Bilec et al. 2010).

Lean production has had a transformative impact on building construction projects in which it has been applied (Koskela 2000; Sacks et al. 2018). Borrowing principles from manufacturing, lean has reduced costs by targeting production waste (Hosseini et al. 2012). Waste, which includes the exhaustion of time, money and energy that returns no value to the end customer, is the most important variable that lean aims to minimize (Womack and Jones 2003). In traditional construction management the quantity of process waste is large because management focuses on transformation alone, rather than the process and associated operations (Koskela 2000). Lean thinking guides the mapping of the process by dividing it into value-adding and non-value-adding activities, with a view to eliminating the non-value-adding activities as far as possible. Some of the wastes, like transporting materials, workers and equipment, cannot be removed completely. These are known as "Type 2 Muda."

Recent studies have focussed on the relationship between lean, BIM and sustainability. Lu et al. (2017) provide an important reference for researchers in the BIM or green fields. They propose "BIM triangle" taxonomy to understand the current body of knowledge on green BIM. Moreover, their study helps to understand the various functions of BIM software for green buildings. Saieg et al. (2018) perform a systematic literature review on the interaction between lean, BIM and sustainability in architecture, engineering and construction (AEC). They review 32 studies that show relationship between these fields. Dixit et al. (2017) studied the relationship between lean construction and sustainability in the Indian construction industry. They reported five lean tools for enabling sustainability: first run studies, six sigma, Kanban, Last Planner System and visualization tools and conclude that the main linkages between sustainability and lean construction are: resource management, waste reduction, energy minimization, elimination of non-value added activities and health and safety improvement.

Golzarpoor and González (2013) propose an integrated green-lean simulation model of a construction project as a case study. This model shows improved time and cost performance, better resource utilization, energy savings and decrease in GHG gas emissions in the project. Carneiro et al. (2012) present theoretical research on the relationship between lean and green. They develop a correlation matrix between lean construction principles and leadership in energy and environmental design (LEED). They argue that lean construction contributes to green building in three pillars of sustainability: economic, environmental and social, since both share the concept of eliminating waste, but the two methods are different in their application. While LEED focuses on sustainability at conception, design and construction phases, lean construction focuses on flow and conversion processes, aiming to improve production processes by removing all non-value adding activities.

Virtual Design and Construction (VDC) is a practice in which both construction products and related construction processes are modelled collaboratively and in detail 
using Building Information Modeling (BIM) tools (Kunz and Fischer 2012; Sacks et al. 2018). VDC is designed to support multi-disciplinary project teams that include multiple engineers, architects, contractors and owner representatives. It provides an integrated method to plan production in construction, removing design conflicts and errors in the virtual world before they can manifest in the real world.

VDC approaches are being combined with life cycle thinking to reduce rework, waste, energy and environmental impact and to recover materials from construction and demolition activities (Akanbi et al. 2018; Honic et al. 2019). For example, Stadel et al. (2011) describe the opportunity to reduce the carbon footprint of buildings by combining BIM and LCA tools.

Our objective in this work was to investigate the potential for reducing waste in operations, materials, and life cycle inputs for masonry walls through VDC and Lean construction principles. Specifically, we used work study methods to compare multiple construction projects managed using three different approaches; Lean, Lean combined with VDC, and traditional. For each, we quantified and compared operational waste, material waste and life cycle GHG emissions.

\section{METHODS AND DATA}

A case study research methodology with quantitative assessment was selected for this study. Two construction companies were selected for study, both of which have extensive expertise in large-scale high-rise residential construction projects. Company A began Lean construction and BIM implementation in 2012 and has made significant progress in transforming its practices. Company B has yet to adopt either of the two innovations.

This study used the same work study and analysis procedure executed by Sacks et al. (2018) in prior experiments with one of company A's construction projects beginning in 2007, before the company began using lean and BIM. We denote the 2007 project 'A1'. The same measurements were repeated in 2014 (project 'A2'), following the company's initial implementation of Lean and BIM. Project A2 applied the Last Planner System for production control without VDC. New data sets were obtained from two projects built during 2019: Project 'A3' used Lean and VDC and company B's project 'B1', which was managed traditionally.

Life cycle assessment (LCA) following ISO 14040 (ISO 2006) was used to calculate the reduction in GHG along the material supply chains of projects A3 and B1. The researchers audited the masonry partition wall construction activities at the construction sites, using a work study approach and monitoring worker activity every five minutes for a full cycle time for whole floor batches of three or four apartments. In projects A3 and B1, a total of 391 worker-hours were audited in three different buildings under construction. The observed workers' activities were categorized as value-adding and nonvalue-adding activities. The value-adding activities included: building, gluing and levelling. The non-value-adding activities included: marking out, moving blocks, cutting, moving between floors, cleaning, scaffolding, waiting, reworking, implementing design changes and others.

We completed a critical analysis for the data collected from the construction sites, decoding the raw work study data, classifying the activity types, and summing the time for each activity and dividing it into the total amount of worker time in order to understand the allocation of time among activities. The goal was to compare project results to identify and to quantify any improvements that could be attributed to Lean and VDC implementation. 
The next sections of this paper describe the data collection activities for masonry works. The latter section describes an inventory of GHG emissions designed to calculate the carbon footprint of the blocks and partitions supply chains, from cradle to installation.

\section{LCA Application to the Construction Process}

The authors used life cycle assessment (LCA) following ISO 14040 (ISO, 2006) methods to calculate the reduction in GHG emissions using the 100 -year global warming potential based on AR4 of IPCC 2007 (Forster et al. 2007) and measured in carbon dioxide equivalents $\left(\mathrm{CO}_{2} \mathrm{e}\right)$ due to implementing lean principles and VDC by company A. The functional unit is defined as the partitions in a 27-floor residential tower with 170 apartments in Tel-Aviv. The building materials used were autoclaved aerated concrete (AAC) blocks, marketed as Ytong, and gypsum blocks. The AAC blocks have a cradleto-gate global warming intensity (GWI) of $327 \mathrm{~kg} \mathrm{CO} 2 \mathrm{e} / \mathrm{t}\left(130.8 \mathrm{~kg} \mathrm{CO}_{2} \mathrm{e} / \mathrm{m}^{3}\right)$ (Huberman and Pearlmutter 2008). The gypsum blocks have a cradle-to-gate GWI of $105.3 \mathrm{~kg} \mathrm{CO} 2 \mathrm{e} / \mathrm{t}$ $\left(89.5 \mathrm{~kg} \mathrm{CO} 2 \mathrm{e} / \mathrm{m}^{3}\right)$ (Fořt and Černý 2018).

For transportation energy it was assumed that the gypsum blocks and Ytong factories are located within a $100 \mathrm{~km}$ radius and the landfills are located within a $50 \mathrm{~km}$ radius. Global warming intensity factor of $67 \mathrm{~g} \mathrm{CO} \mathrm{CO}_{2} /$ tonnes-km was adopted for all transportation of materials, based on typical fuel consumption and related energy costs of trucking (Ashby 2013). The system boundary for the Lean-VDC and traditional cases evaluated includes manufacture of the blocks, transportation to the site, and transportation of the wastes to the landfill. The main difference between the two system boundaries is the role of Lean and VDC in governing the production planning and control of the process.

\section{CASE STUDY DESCRIPTION AND EMPRICAL DATA}

Data collected from the 2007 case (A1) motivated company A's management to start thinking about waste. Value-added activities accounted for just $31.9 \%$ of the total working time, with the remaining time spent on non-value adding activities including: cutting $24.1 \%$, scaffold $2 \%$, marking out $7.3 \%$, filling end grooves $2.6 \%$, transporting blocks $4.4 \%$, move between storeys $0.4 \%$, design changes $7 \%$ and waiting and rework $10.5 \%$ (Sacks et al. 2018).

The first action undertaken by company A was value stream mapping (VSM). The traditional method delivers blocks in one of two ways; either they are transported to the floor through the window openings and balconies after casting the concrete slab above, or they are stacked, two pallets high, within the floor before pouring the slab. Stacking the pallets on top of each other causes many problems. First, the amount of block waste increases because the top pallet imposes high stress on the lower pallet, damaging the blocks on the top layer of the lower pallet. Also, since the top layer of the top pallet is near the ceiling, the formwork often falls onto the blocks when the jacks for the formwork are removed (Sacks et al. 2018).

From the lean perspective all these activities are considered waste because they do not add any value to the final product, the partition wall. These activities can be avoided by looking to the process itself and trying to remove these waste activities. If the pallets are distributed to the right location and in the correct quantities, avoiding stacking pallets on top of each other, and all the constraints for all the activity were removed, the workers will spend less time and effort addressing these activities. Also, the quantity of wasted materials will reduce significantly because as noted above, placing the pallets on top of each other plays a key role in destruction of the blocks. 
Block work activity was monitored in one of company A's most recent projects in 2019 in Tel-Aviv (project A3). The scope of this project is a 27-floor residential tower with 170 apartments. VDC using Revit and Lean principles were applied in this project. VDC produced highly detailed fabrication models for the partitions which accounted for all openings and optimized the arrangement of rows from floor to ceiling. During preparation of the VDC model, the VDC manager shared the ideas with the different subcontractors, who in turn eliminated the clashes between different trades' systems during construction. VDC played an important role in reducing the scope and frequency of changes that result from lack of coordination between different design disciplines. In this project three types of blocks were used: Ytong (AAC) blocks, water resisting gypsum blocks and normal gypsum blocks. The quantities of blocks of each type were calculated for each apartment from the VDC model, and the pallets were delivered and distributed accordingly to the right locations with the right quantities, with no stacking. Detailed partition layouts, extracted from the VDC model, were provided to masons in every apartment. . The drawings were provided on site in full color to distinguish the different types of blocks. The site superintendents printed these layouts and posted them at the entrance to each apartment before the workers arrived in order eliminate waiting for drawings. The experiment included observation of three masons every five minutes and registering their activity. After finishing a full cycle time for three apartments over five days, the data were analyzed by summing the time spent on each activity and dividing it by the total amount of time each worker spent on individual activities in order to get the percentage for each activity.

A second building project case study, in which lean construction principles (primarily Last Planner ${ }^{\circledR}$ System) were applied without VDC, was investigated in a neighbourhood near Tel-Aviv. The scope of this project was two 15 story residential buildings with 134 apartments. The masons' activity was monitored using the same method applied in project A3.

Finally, a third project was examined in 2019, in which observations were made for one construction site managed through traditional means, with neither VDC nor lean. The scope of the project was similar in scale to company A's building in Tel Aviv in 2019 (project A3), and consisted of a neighborhood of four buildings, three of them are 10 storey buildings and the fourth is a 20 -storey tower, with a total of 244 apartments.

\section{FINDINGS AND RESULTS}

The three projects studied were inventoried for worker activity. Results show that there is a large difference in worker activity due to VDC and Lean implementation. Consistently, value-adding activities are higher for projects managed through VDC and Lean and non-value-adding activities are highest for traditional management. Table 1 lists the set of value-adding and non-value adding activities according to the masonry wall operations. The results for the project with lean and VDC (A3) have the greatest percentage of value-adding activities relative to non-value-adding activities (Figure 1).The results for project $A 2$, Lean without VDC, have slightly worse results. The results for projects $\mathrm{A} 1$ and $\mathrm{B} 1$, with traditional management have the lowest proportions of value-adding activities. 

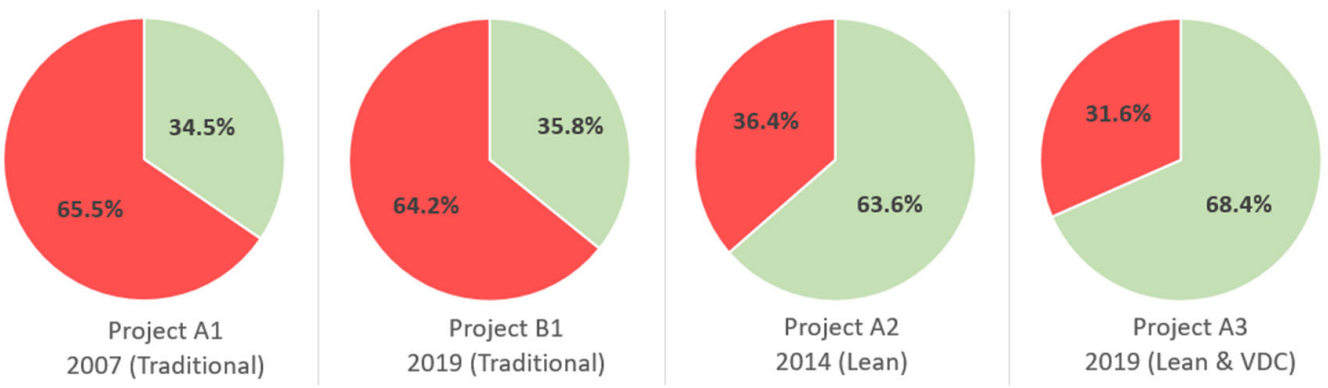

Figure 1: Results for four projects showing proportions of value-adding (green) and non-value-adding (red) activities for masonry construction operations

Table 1: Summary of the results of activities observed in four work studies. Values are the percent proportion of the total working time time spent on each activity

\begin{tabular}{ccccc}
\hline Work activity & $\begin{array}{c}\text { Project A1 } \\
\mathbf{2 0 0 7} \\
\text { (Traditional) }\end{array}$ & $\begin{array}{c}\text { Project A2 } \\
\mathbf{2 0 1 4} \text { (Lean) }\end{array}$ & $\begin{array}{c}\text { Project A3 } \\
\mathbf{2 0 1 9} \text { (Lean \& } \\
\text { VDC) }\end{array}$ & $\begin{array}{c}\text { Project B1 } \\
\mathbf{2 0 1 9} \\
\text { (Traditional) }\end{array}$ \\
\hline $\begin{array}{c}\text { Building, gluing and } \\
\text { levelling }\end{array}$ & 34.5 & 63.6 & 68.4 & 35.8 \\
Cutting & 24.1 & 7.8 & 1.3 & 12.6 \\
Moving pallets & 4.4 & 1.3 & 4.8 & 19.0 \\
Move between storeys & 0.4 & 1.3 & 1.9 & 3.7 \\
Cleaning & 9.9 & 5.2 & 4.9 & 5.7 \\
Marking out & 7.3 & 11.7 & 3.5 & 5.6 \\
Scaffold & 2.0 & 0.0 & 0.3 & 1.2 \\
Waiting and rework & 10.5 & 3.9 & 6.1 & 6.6 \\
Design changes and & 7.0 & 5.2 & 8.8 & 10.0 \\
others & & & & \\
Total & 100.0 & 100.0 & 100.0 & 100.0 \\
\hline
\end{tabular}

In project B1 (traditional 2019) a significant amount of waste was observed in the operations associated with the masonry partition wall process. Furthermore, the flow of subcontractors was not continuous, leading to a fragmented sequence of building operations. For example, on the 6th of October 2019, two block workers arrived at the construction site. Other workers from the same contactor had completed the patitions on the previous floor three weeks earlier, but because the plan did not consider the flow of the trades between the locations, the subcontractors had to move between different projects for different companies. The workers began preparing the prerequisites for the work by bringing electrical cables, requesting water from the site superintendent to prepare the mortar, bringing a container for mixing, asking for the drawings to mark out the location for the partition walls, etc. The mortar in the work location was insufficient, so they asked the site superintendent to deliver it by the crane to the open balcony, and they transported it into the floor. Pallets of blocks had been delivered o the floor prior to casting of the ceiling slab, as planned, but they were distributed in haphazard fashion and stacked two pallets high. Some apartments had large numbers of pallets, while others had none. The estimated quantity for the floor was 48 pallets, but only 30 pallets were 
delivered - the remainder has to be delivered by crane to the open balcony. Work began with $5 \mathrm{~cm}$ thick blocks, which are applied to cover external walls, but in some pallets of $10 \mathrm{~cm}$ blocks were placed on top of pallets of $5 \mathrm{~cm}$ blocks - this required manual unpacking. Blocks in the topmost layers were often damaged - Figure 2 shows a pallet in which the top layer was entirely destroyed. Damaged blocks had to be carried to the open balcony for removal by crane and disposal to landfill.

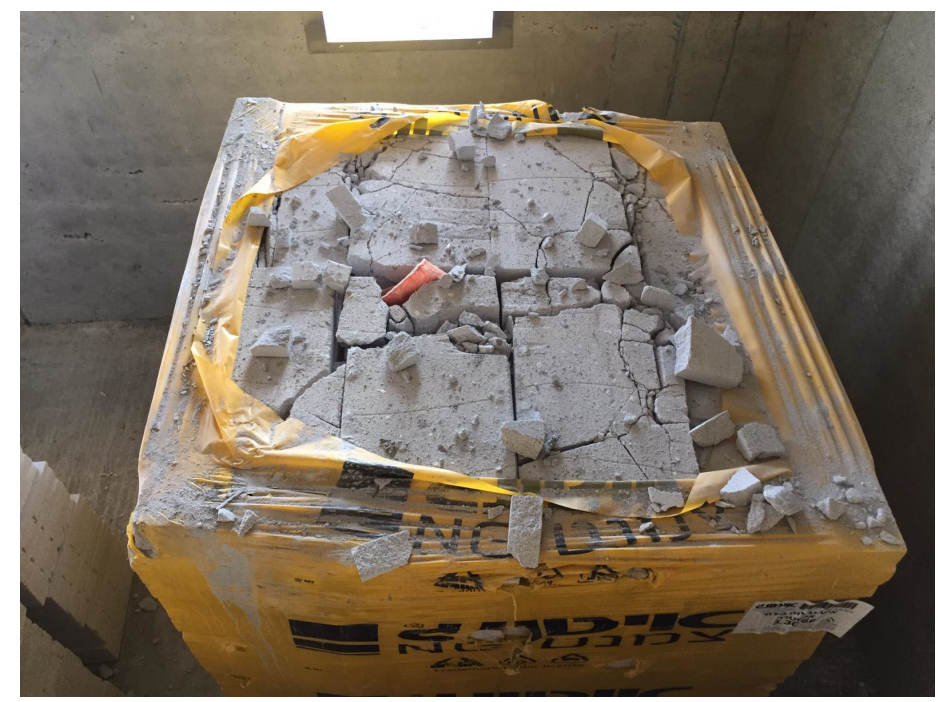

Figure 2: Completely damaged top layer of a pallet of Ytong blocks

Similar issues recurred in the next floor on which work was observed, floor 20. Multiple interruptions to work were recorded. Planning of the work did not consider the workflow from the point of view of the crews - continuity for subcontractors and labourers was not a factor. In this project a more severe problem occurred - one of the workers fell from a $0.9 \mathrm{~m}$ high table scaffold and injured his head, not a surprising event given the weak level of control at the site, and given the unfamiliarity of the worker with the environment as he had recently arrived on site, as part of the frequent rotation of workers. Statistics show that the probability of injury is higher on a worker's first day on a new site (Rozenfeld et al. 2010).

Among the results from these case studies (see Table 1), we observe that VDC appears to play an important role in reducing the need for cutting blocks to size. Project A3 (Figure 3 ), the project with VDC, had $1.3 \%$ cutting, while projects $\mathrm{A} 2$ and $\mathrm{B} 1$ had $7.8 \%$ and $12.6 \%$, respectively. Moving blocks was also a key factor in distinguishing the traditional projects from those with lean and VDC. Clearly this can be avoided by delivering the blocks in the right quantities to the right locations. 


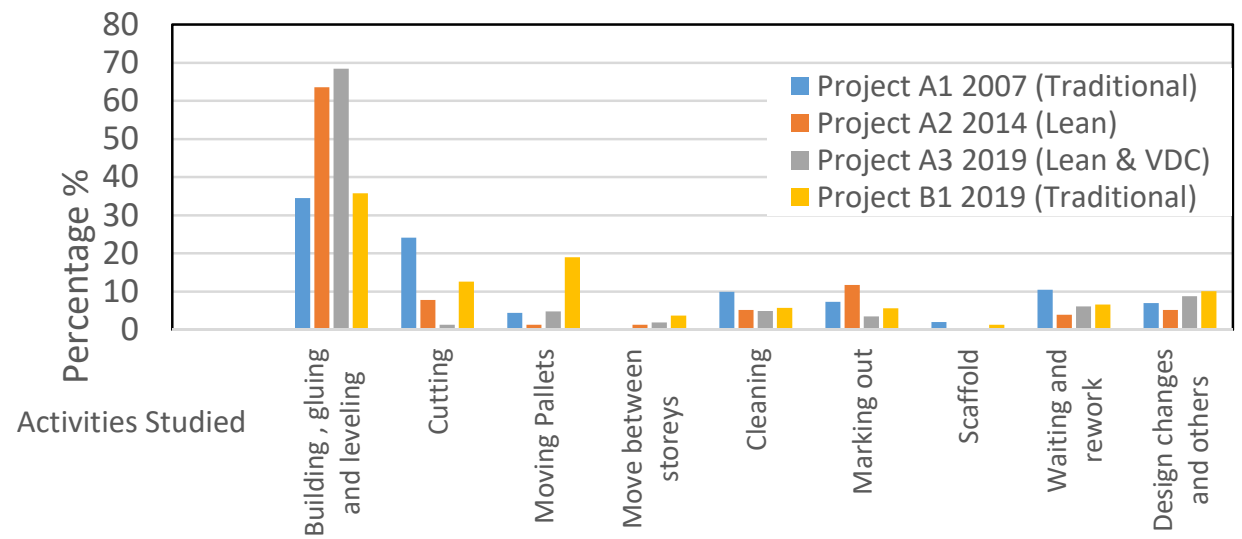

Figure 3: Distribution of activities observed in four work studies: A1 2007 (traditional), A2 2014 (Lean), A3 2019 (Lean and VDC) and B1 2019 (traditional)

\section{GREENHOUSE GAS EMISSIONS}

This section evaluates the GHG of the two types of blocks used in the three projects. The Ytong block type was used in the traditional project, while both block types (gypsum and Ytong) were used in the Lean and VDC managed projects.

From an environmental impact perspective, Lean and VDC had a significant influence on reducing the global warming potential (GWP) of the construction of multi-unit residential buildings, as can be seen from the data analysis in Table 2 . The traditionally managed project had a net GWP of $169 \mathrm{t} \mathrm{CO}_{2} \mathrm{e} / \mathrm{m}^{3}$ with $62.4 \mathrm{t} \mathrm{CO} 2 \mathrm{e}$ waste, which signifies a waste of $27 \%$. The Lean and VDC managed project had a GWP of $112 \mathrm{t} \mathrm{CO}_{2} \mathrm{e} / \mathrm{m}^{3}$ with 21.8 t $\mathrm{CO} 2 \mathrm{e}$ waste, a waste of $10 \%$. Comparing the traditionally managed project and the lean and VDC project, the GWP of embodied block waste in the former is approximately three times that of the latter and the embodied GWP of the final built blocks were $33 \%$ lower for the Lean and VDC compared to the traditionally managed project.

However, some proportion of the difference is due to the fact that the traditional project exclusively used blocks with higher embodied GWP. Thus, to investigate the effect of Lean and VDC independent of block material, we compare traditional and VDC projects under the artificial assumption that both had used gypsum blocks alone (Table 3). In this "control" case, total block waste and GWP embodied in block waste do not change significantly from the case where Ytong blocks alone are used in the traditional project and a combination of Ytong and gypsum blocks are used in the Lean and VDC project. This analysis shows that the GWP per volume of block partitions actually built (an indicator of the GWP per unit floor area) for the traditionally managed project is $13 \%$ greater than the Lean and VDC case. 
Table 2: Waste and GWP from traditional and lean/VDC management

\begin{tabular}{|c|c|c|c|c|}
\hline \multirow[t]{2}{*}{$\begin{array}{c}\text { Inventoried Data and Performance } \\
\text { Metrics }\end{array}$} & \multirow{2}{*}{$\begin{array}{c}\begin{array}{c}\text { Traditional } \\
\text { management }\end{array} \\
\text { Ytong block }\end{array}$} & \multicolumn{3}{|c|}{$\begin{array}{c}\text { Lean and VDC } \\
\text { management }\end{array}$} \\
\hline & & $\begin{array}{l}\text { Ytong } \\
\text { block }\end{array}$ & $\begin{array}{c}\text { Gypsu } \\
\text { m } \\
\text { block }\end{array}$ & Total \\
\hline Delivered quantities $\left(\mathrm{m}^{3}\right)$ & 2,225 & 344 & 1,969 & 2,313 \\
\hline Block volume built $\left(\mathrm{m}^{3}\right)$ & 1,762 & 334 & 1,759 & 2,093 \\
\hline Waste volume $\left(\mathrm{m}^{3}\right)$ & 463 & 10 & 210 & 220 \\
\hline Delivered blocks (ton) & 890 & 138 & 1,674 & 1,812 \\
\hline Blocks built (ton) & 705 & 134 & 1,495 & 1,629 \\
\hline Block waste generated (ton) & 185 & 4 & 179 & 183 \\
\hline No. of pallets & 1,646 & 251 & 2,587 & \\
\hline No. of truckloads & 55 & 9 & 86 & \\
\hline Distances travelled $(\mathrm{km})$ & 5,500 & 900 & 8,600 & \\
\hline $\begin{array}{l}\text { Transportation of unused blocks to site } \\
\qquad(\mathrm{km})\end{array}$ & 1,000 & 0 & 900 & \\
\hline Transportation of waste from site $(\mathrm{km})$ & 500 & 0 & 450 & \\
\hline Block embodied GWP (t $\left.\mathrm{CO}_{2} \mathrm{e}\right)$ & 291 & 44.9 & 176.2 & 221.1 \\
\hline Block transport to site $\left(\mathrm{t} \mathrm{CO}_{2} \mathrm{e}\right)$ & 6 & 0.9 & 11.2 & 12.1 \\
\hline $\begin{array}{l}\text { Embodied GWP in transport to landfill } \\
\qquad\left({\left.\mathrm{t} \mathrm{CO}_{2} \mathrm{e}\right)}^{\text {E }}\right.\end{array}$ & 0.6 & 0.00 & 0.6 & 0.6 \\
\hline Total embodied $\left(\mathrm{t} \mathrm{CO}_{2} \mathrm{e}\right)$ & 297.6 & 45.8 & 188 & 233.8 \\
\hline Total embodied GWP in waste $\left({\left.\mathrm{t} \mathrm{CO}_{2} \mathrm{e}\right)}\right.$ & 62.4 & 1.2 & 20.6 & 21.8 \\
\hline GWP per block volume built $\left(\mathrm{kg} \mathrm{CO}_{2} \mathrm{e} / \mathrm{m}^{3}\right)$ & 169 & 137 & 107 & 112 \\
\hline GWP waste percentage (\%) & 27 & 3 & 12 & 10 \\
\hline
\end{tabular}


Table 3: Hypothetical case of gypsum block used by both traditional and lean and VDC management approaches

\begin{tabular}{ccc}
\hline Inventoried Data and Performance Metrics & $\begin{array}{c}\text { Traditional } \\
\text { management }\end{array}$ & $\begin{array}{c}\text { Lean and VDC } \\
\text { management }\end{array}$ \\
\hline Delivered quantities $\left(\mathrm{m}^{3}\right)$ & Gypsum block & Gypsum block \\
Block volume built $\left(\mathrm{m}^{3}\right)$ & 2,225 & 2,313 \\
Waste volume $\left(\mathrm{m}^{3}\right)$ & 1,762 & 2,093 \\
Delivered blocks (ton) & 463 & 220 \\
Blocks built (ton) & 1,891 & 1,966 \\
Block waste generated (ton) & 1,498 & 1,779 \\
No. of pallets & 393 & 187 \\
Distances traveled $\left(\mathrm{km}^{2}\right)$ & 2,923 & 3,028 \\
Block embodied GWP $(\mathrm{t} \mathrm{CO} 2 \mathrm{e})$ & 9,800 & 10,100 \\
Block transport to site $\left(\mathrm{t} \mathrm{CO} \mathrm{CO}_{2}\right)$ & 199.1 & 207 \\
Embodied GWP in transport to landfill $(\mathrm{t} \mathrm{CO} 2 \mathrm{e})$ & 12.7 & 13.2 \\
Total embodied $\left(\mathrm{t} \mathrm{CO}_{2} \mathrm{e}\right)$ & 2.6 & 0.63 \\
Total embodied GWP in waste $\left(\mathrm{t} \mathrm{CO}{ }_{2} \mathrm{e}\right)$ & 214.4 & 221 \\
GWP per block volume built $\left(\mathrm{kg} \mathrm{CO}_{2} \mathrm{e} / \mathrm{m}^{3}\right)$ & 46.7 & 21.6 \\
GWP waste percentage $(\%)$ & 122 & 106 \\
\hline
\end{tabular}

\section{CONCLUSIONS}

The three construction projects analyzed herein demonstrate that lean principles play an important role in improving value-adding activities and waste reduction. The valueadding activities in the traditionally managed project were $35.8 \%$ of the total, while the comparable Lean and Lean \& VDC project values were $66.3 \%$ and $68.4 \%$, respectively. Lean and VDC approaches most significantly reduced waste in moving blocks and in cutting operations. The results underscore the importance of avoiding pallet stacking since this practice adds much time and damages blocks.

From an environmental impact perspective, we conclude that Lean and VDC have a significant impact on reducing the GWP of the construction process. In the traditionally managed project the percentage of material waste was $27 \%$, while in the Lean \& VDC managed project material waste was $11 \%$.

There is a dual benefit from implementing Lean and VDC. On the one hand, design and planning in advance lead to improved operational and material efficiency, as evidenced in the value-adding time and in the quantity of blocks delivered and used in projects $\mathrm{A} 2$ and $\mathrm{A} 3$ compared to projects $\mathrm{A} 1$ and $\mathrm{B} 1$. On the other hand, this also has a multiplying effect on the overall carbon intensity of the building, where the Lean \& VDC projects consume smaller quantities of materials and generate less material waste and GHG emissions. Overall, for the sample projects studied, Lean \& VDC management reduced wasted GWP from $169 \mathrm{~kg} \mathrm{CO} 2 \mathrm{e} / \mathrm{m}^{3}$ of partition built to $112 \mathrm{~kg} \mathrm{CO} 2 \mathrm{e} / \mathrm{m}^{3}$, an environmental improvement of 34\%. Even when comparing the traditional project with the Lean \& VDC project, where block type is normalized, the Lean \& VDC project still 
had a lower total GWP per block volume and significantly lower embodied GWP in block waste. We estimate that $13 \%$ of the overall $33 \%$ reduction was due to Lean and VDC application, and the remaining $20 \%$ due to the change from cement-based ACC blocks to gypsum blocks.

\section{ACKNOWLEDGMENT}

Partial funding for this research was provided by Tidhar Construction Inc. The authors are indebted to those of the company's employees who supported the research on site.

\section{REFERENCES}

Akanbi, L. A., Oyedele, L. O., Akinade, O. O., Ajayi, A. O., Delgado, M. D., Bilal, M., and Bello, S. A. (2018). "Salvaging building materials in a circular economy: A BIMbased whole-life performance estimator." Resources, Conservation and Recycling, 129, 175-186.

Ashby, M. F. (2013). Materials and the environment: eco-informed material choice. $2^{\text {nd }}$ Ed., Butterworth-Heinemann-Elsevier-New York.

Bhardwaj, B., and Kumar, P. (2019). "Comparative study of geopolymer and alkali activated slag concrete comprising waste foundry sand." Construction and Building Materials, 209, 555-565.

Bilec, M. M., Ries, R. J., and Matthews, H. S. (2010). "Life-cycle assessment modeling of construction processes for buildings." J. Infrastructure Systems, 16(3), 199-205.

Carneiro, S. B. D. M., Campos, I. B., Oliveira, D. M. D., and Barros Neto, J. D. P. (2012). "Lean and green: a relationship matrix." Proc. $20^{\text {th }}$ Annual Conference of the International Group for Lean Construction, San Diego, Calif., USA.

Dixit, S., Mandal, S. N., Sawhney, A., and Singh, S. (2017). "Area of linkage between lean construction and sustainability in Indian construction industry." International Journal of Civil Engineering and Technology, 8(8).

Forster, P., Ramaswamy, V., Artaxo, P., Berntsen, T., Betts, R., Fahey, D. W., and Nganga, J. (2007). "Changes in atmospheric constituents and in radiative forcing." Chapter 2. In Climate Change 2007. The Physical Science Basis.Contribution of Working Group I to the Fourth Assessment Report of the Intergovernmental Panel on Climate Change, Solomon, S.; Qin, D.; Manning, M.; Marquis, M.; Averyt, K.; Tignor, M.M.B.; Miller, H.L., Eds. Cambridge University Press: New York, NY.

Fořt, J., and Černý, R. (2018). "Carbon footprint analysis of calcined gypsum production in the Czech Republic." Journal of Cleaner Production.

Fu, F., Sun, J., and Pasquire, C. (2015). "Carbon Emission Assessment for Steel Structure Based on Lean Construction Process." Journal of Intelligent and Robotic Systems: Theory and Applications.

Golzarpoor, H., and González, V. (2013, July). "A green-lean simulation model for assessing environmental and production waste in construction." Proc. $21^{\text {st }}$ Annual Conference of the International Group for Lean Construction, Fortaleza, Brazil (pp. 885-894)

Honic, M., Kovacic, I., and Rechberger, H. (2019). "Improving the recycling potential of buildings through Material Passports (MP): An Austrian case study." Journal of Cleaner Production, 217, 787-797.

Horvath, A. (2004). "Construction Materials and the Environment." Annual Review of Environment and Resources, 29(1), 181-204. 
Hosseini Nasab, H., Aliheidari Bioki, T., and Khademi Zare, H. (2012). "Finding a probabilistic approach to analyze lean manufacturing." Journal of Cleaner Production, 29-30, 73-81.

Huberman, N., and Pearlmutter, D. (2008). "A life-cycle energy analysis of building materials in the Negev desert." Energy and Buildings, 40(5), 837-848.

ISO. (2006). ISO 14040 International Standard. Environmental management - Life cycle assessment - Principles and framework. https://www.iso.org/standard/37456.html

Koskela, L. (2000). An exploration towards a production theory and its application to construction. VTT Technical Research Centre of Finland.

Kunz, J., and Fischer, M. (2012). Virtual Design and Construction: Themes, Case Studies and Implementation Suggestions. CIFE Working Paper, 97(Version14), 50. Retrieved fromhttp://www.stanford.edu/group/CIFE/online.publications/WP097.pdf

Lu, Y., Wu, Z., Chang, R., and Li, Y. (2017). "Building Information Modeling (BIM) for green buildings: A critical review and future directions." Automation in Construction, 83, 134-148.

McIntyre, J., Spatari, S., and MacLean, H.L. (2009). "Energy and greenhouse gas emissions trade-offs of recycled concrete aggregate use in nonstructural concrete: A North American case study." Journal of Infrastructure Systems, 15(4), 361-370.

Pasqualini, F. and Zawislak, P. A. (2005). "Value Stream Mapping in Construction: A Case Study in a Brazilian Construction Company." Proc. $13^{\text {th }}$ Annual Conference of the International Group for Lean Construction. Sydney, Australia, 19-21 July, pp. 117-125.

Rozenfeld, O., Sacks, R., Rosenfeld, Y., and Baum, H. (2010). "Construction Job Safety Analysis." Safety Science, 48(4), 491-498.

Sacks, R., Eastman, C. M., Lee, G., Teicholz, P., (2018). BIM Handbook: A Guide to Building Information Modeling for Owners, Designers, Engineers, Contractors and Facility Managers. 3rd Edition, John Wiley and Sons, Hoboken NJ, ISBN 978-1119-28753-7, 688 pages.

Sacks, R. (2016). "What constitutes good production flow in construction?" Construction Management and Economics, 34(9), 641-656.

Sacks, R., Korb, S., and Barak, R. (2017). Building Lean, Building BIM: Improving Construction the Tidhar Way. Routledge, Taylor and Francis, Oxford UK, ISBN 9781-138-23722-3, 407 pages.

Saieg, P., Sotelino, E. D., Nascimento, D., and Caiado, R. G. G. (2018). "Interactions of building information modeling, lean and sustainability on the architectural, engineering and construction industry: a systematic review." Journal of Cleaner Production, 174, 788-806.

Stadel, A., Eboli, J., Ryberg, A., Mitchell, J., and Spatari, S. (2011). "Intelligent Sustainable Design: Integration of Carbon Accounting and Building Information Modeling." Journal of Professional Issues in Engineering Education and Practice, 137(2), 51-54.

Womack, J.P. and Jones, D.T. (2003) Lean Thinking: Banish Waste and Create Wealth in Your Corporation. $2^{\text {nd }}$ Edition Simon and Schuster, New York, NY. 